\title{
Kesadaran Lingkungan dalam Perubahan Iklim
}

\author{
Sheila Nurul Fajar, Dede Lilis Chaerowati \\ Prodi Manajemen Komunikasi, Fakultas Ilmu Komunikasi, Universitas \\ Islam Bandung, Indonesia. \\ *sheilanurulf@gmail.com,dede.lilis@unisba.ac.id
}

\begin{abstract}
Film is one of the communication media that can be used to convey or provide information to the wider community. Along with its development, films have a considerable impact on the wider community. This happens because films have their own way of conveying information through interesting stories. One of the films that is deliberately produced to convey information is the film called "Semesta". This film shows people how environmental activities are carried out by seven great figures in seven different provinces in Indonesia. The purpose of this research itself is to see environmental awareness aspects in climate change through the environmental communication perspective in the film "Semesta". The research method used is qualitative with John Fiske's semiotic model, so the data analysis technique uses the technique from John Fiske, where the code of findings is analyzed into three levels, reality, representation and ideology. The data for the research will be collected by doing observations, documentation, literature study, and interviews about the related film. The collected data will then be analyzed by reducing the data, presenting the data and finally drawing conclusion. This research will produce knowledge about the construction of the reality level code of behavior and the dialogue of the film characters who show environmental awareness. Then at the representation level shown from the camera code and editing that supports message packaging. At the ideological level, there are elements of inherited religion and culture as well as elements of women's emancipation. And environmental communication that conforms to the code of the three levels describes an effective environmental communication message.
\end{abstract}

Keywords: John Fiske's Semiotic Model, Environmental Communication, Environmental Awareness, Climate Change, Semesta Film.

Abstrak. Film merupakan salah satu media sarana komunikasi yang bisa digunakan untuk menyalurkan atau memberikan informasi terhadap masyarakat luas. Seiring dengan perkembangannya, film memberikan dampak yang cukup besar pada masyarakat luas, hal ini terjadi karena film mempunyai caranya sendiri dalam menyampaikan informasi melalui cerita yang menarik. Salah satu film yang sengaja diproduksi untuk menyampaikan informasi merupakan film "Semesta". Film ini memperlihatkan mengenai bagaimana kegiatan peduli lingkungan yang dilakukan oleh tujuh sosok hebat di tujuh provinsi berbeda di Indonesia. Tujuan dilakukannya penelitian ini sendiri adalah untuk mengetahui aspek kesadaran lingkungan dalam perubahan iklim dalam perspektif komunikasi lingkungan yang ada di film "Semesta". Metode penelitian yang digunakan adalah Kualitatif dengan model semiotika John Fiske, sehingga teknis analisis data menggunakan teknik dari John Fiske, di mana kode temuan dianalisis ke dalam tiga level, realitas, representasi dan ideologi. Pengumpulan data akan dilakukan dengan dengan melakukan observasi, dokumentasi, studi pustaka, dan wawancara mengenai film terkait. Data yang terkumpul lalu akan dianalisis dengan cara mereduksi data, menyajikan data dan akhirnya menarik kesimpulan. Penelitian ini menghasilkan pengetahuan mengenai konstruksi level realitas dari kode perilaku dan dialog tokoh film yang menunjukkan kesadaran lingkungan. Lalu pada level representasi diperlihatkan dari kode kamera dan editing yang mendukung pengemasan pesan. Dalam level ideologi terdapat unsur agama dan budaya waris juga unsur emansipasi wanita. Dan disimpulkan dengan ditampilkannya kode dari ketiga level tersebut tergambar suatu pesan komunikasi lingkungan mengenai kesadaran lingkungan yang efektif.

Kata Kunci: Semiotika John Fiske, Komunikasi Lingkungan, Kesadaran Lingkungan, Perubahan Iklim, Film Semesta 


\section{A. Pendahuluan}

Dunia saat ini sedang menghadapi perubahan iklim yang buruk. Perubahan iklim sendiri bukanlah masalah yang baru terjadi belakangan, masalah ini sudah banyak disuarakan sejak dulu. Bahkan banyak sekali gerakan-gerakan yang muncul di masyarakat untuk melawan perubahan iklim ini. Perubahan iklim sendiri merupakan perubahan suhu, curah hujan, pola angin dan berbagai efek lain secara drastis yang terjadi pada bumi, tempat kita tinggal.

Fenomena perubahan iklim yang terjadi saat ini merupakan salah satu penyabab terjadinya banyak bencana yang terjadi di dunia. Di Indonesia sendiri, kini banyak sekali masalah-masalah lingkungan yang terjadi, menurut artikel "Tantangan Kita Bersama di Tahun 2020" yang diterbitkan oleh Greenpeace Indonesia pada web greenpeace.org (2020), permasalahan tersebut adalah sebagai berikut:

1. Terkikisnya hutan di Indonesia. Greenpeace mencatat bahwa seluas 3.403 .000 hektar lahan terbakar pada tahun 2015-2018 di Indonesia.

2. Kondisi terumbu karang dan laut Indonesia yang makin memburuk. Tercatat terakhir pada tahun 2019, sebanyak 35,15\% terumbu karang yang ada di Indonesia dikategorikan dalam kondisi yang tidak baik.

3. Plastik dan ketergantungan masyarakat. Dilansir dari katadata.co.id, negara Indonesia sendiri telah menghasilkan kurang lebih 64 juta ton sampah per tahunnya

4. Energi kotor dan polusi udara. Maraknya orang yang menggunakan transportasi pribadi juga menjadi salah satu hal yang menyebabkan kualitas udara menjadi buruk di beberapa daerah. Selain itu, energi kotor juga dihasilkan dari PLTU Batu Bara di Indonesia. Justru sebanyak $20-30 \%$ polusi udara di Jakarta adalah merupakan energi kotor buangan yang dihasilkan dari sisa pembakaran PLTU Batu Bara.

Masalah-masalah lingkungan yang terjadi merupakan cerminan dari minimnya kesadaran lingkungan yang dimiliki oleh masyarakat Indonesia. Menurut artikel dari Breakthrough National Centre for Climate Restoration (2019) yang dimuat pada situs National Geographic, peradaban manusia diperkirakan akan berakhir pada tahun 2050 jika kita tidak melakukan pencegahan mengenai perubahan iklim. Maka dari itu, penting bagi kita masyarakat Indonesia untuk menyadari pentingnya lingkungan. Hal mengenai kesadaran lingkungan dan perubahan iklim dapat kita pelajari dari komunikasi lingkungan. Sehingga, diperlukannya komunikasi lingkungan yang baik sebagai bentuk edukasi untuk masyarakat. Komunikasi lingkungan sendiri bisa disampaikan melalui berbagai macam bentuk salah satunya melalui media film.

Film adalah pilihan media yang tepat untuk dipilih sebagai saluran penyampaian informasi mengenai komunikasi lingkungan dalam kesadaran lingkungan. Di Indonesia sendiri, jumlah penonton film terus meningkat dari tahun ke tahunnya. Menurut data dari perusahaan MD Pictures tahun 2019 dalam web idx.co.id, jumlah rata-rata peningkatan penonton per tahunnya dari tahun 2015-2019 adalah sebanyak kurang lebih 7.2 juta orang.

Gambar 1. STYLEREF 1 \s 1.1 Jumlah Penonton Film di Indonesia Tahun 2015-2019

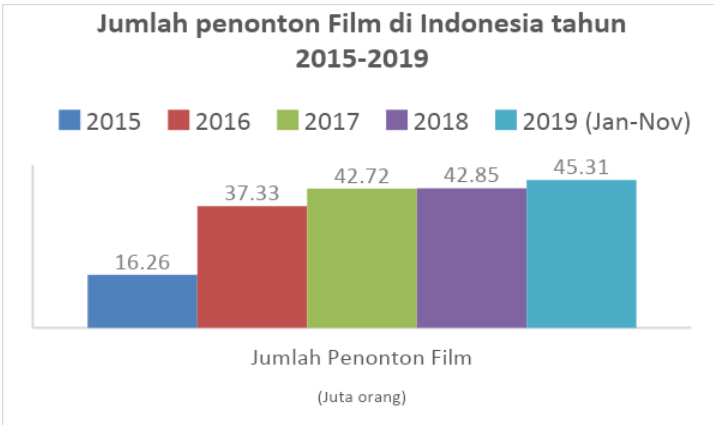

Sumber: MD Pictures (idx.co.id) (diolah oleh penulis) 
Selain karena jumlah penonton film di Indonesia yang semakin tahun semakin meningkat, sifat film yang informatif dan edukatif dapat menjadikan nilai-nilai yang terkandung dalam film tersebut lebih mudah dimengerti dan dicerna. Seperti yang kita ketahui, film juga diketahui sebagai media komunikasi, film dianggap sebagai media yang efektif untuk mempersuasi masyarakat dengan pesan yang disampaikannya. (McQuail, 2011 : 34).

Film yang mengangkat tema mengenai komunikasi lingkungan dalam kesadaran lingkungan salah satunya adalah film "Semesta". Seperti yang dilansir National Geographic dalam artikel "Film Semesta, Kisah 7 Sosok yang Berusaha Memperlambat Dampak Perubahan Iklim" (2020) yang diunggah dalam laman resminya, nationalgeographic.grid.id, film ini di rilis di bioskop Indonesia secara bergilir mulai dari tanggal 30 Januari 2020 lalu. Film yang disutradarai oleh Nicholas Saputra ini sebelumnya telah berhasil masuk dalam nominasi "film dokumenter panjang terbaik" yang ada dalam Festival Film tahun 2018. Selain itu, "Semesta" juga terpilih sebagai salah satu film yang diputar di Suncine International Environmental Film Festival (SIEFF) yang merupakan sebuah festival film khusus untuk film dokumenter bertema lingkungan, pada tanggal 6-14 November 2019 di Barcelona, Spanyol.

Pentingnya kesadaran lingkungan dalam perspektif komunikasi lingkungan yang ada dalam masyarakat dapat mencegah tindakan kita dari melakukan sesuatu hal yang bersifat merugikan bagi alam dan lingkungan sekitar kita. Maka dari itu, dari penjelasan di atas, saya tertarik untuk melakukan penelitian untuk mengetahui aspek kesadaran lingkungan dalam perubahan iklim dalam perspektif komunikasi lingkungan yang ada di film "Semesta" menggunakan pendekatan semiotika dengan metode analisis John Fiske, karena penelitian ini bertujuan untuk mengetahui bagaimana representadi di level realitas, representasi dan ideologi, dari komunikasi lingkungan yang disampaikan dalam film "Semesta". Penulis akan melakukan penelitian yang berjudul KESADARAN LINGKUNGAN DALAM PERUBAHAN IKLIM (Studi Semiotika John Fiske terhadap Film Dokumenter "Semesta" dalam Perspektif Komunikasi Lingkungan).

\section{B. Metodologi Penelitian}

Penelitian ini menggunakan metode kualitatif dengan paradigma konstruktivis. Paradigma konstruktivis melihat realitas atau kenyataan sebagai hasil bentukan dari intrerpretasi manusia. Pendekatan yang digunakan dalam penelitian ini adalah pendekatan semiotika oleh John Fiske. John Fiske berpendapat bahwa komunikasi selalu melibatkan tanda (sign) dan kode (code).

Melalui teori ini, Fiske menjelaskan bahwa realitas tidak semata-mata terbentuk melalui kode yang ada, tetapi juga disaring dan diolah melalui pandangan sesuai pengetahuan yang dimiliki oleh penonton televisi, yang menjadikan sebuah kode kemudian diolah dan dimengerti secara berbeda oleh setiap individunya.

Objek penelitian yang ada dalam penelitian ini merupakan film documenter "Semesta" yang di produksi oleh Tanakhir Films dan di produseri oleh Nicholas Saputra serta Mandy Marahim. Pada penelitian ini, berdasarkan kebutuhan analisa dan pengkajian, peneliti menggunakan teknik pengumpulan data studi teks visual, dokumentasi, studi pustaka, dan wawancara yang terbagi menjadi data primer dan sekunder.

Analisis data dilakukan dengan menggunakan teknik analisis semiotika oleh John Fiske, di mana terdapat tiga level yang dikemukakan untuk menganalisa elemen dari film tersebut, yaitu :

1. Level of reality

2. Level of representation

3. Level of ideology

Data yang sudah diperoleh, kemudian diuji menggunakan teknik triangulasi, sehingga data tersebut dapat dipahami sesuai dengan maksud dan tujuan penelitian sebagaimana mestinya. Triangulasi yang digunakan dalam penelitian ini adalah triangulasi sumber, di mana hasil data pengamatan yang sudah terkumpul seperti data studi teks visual, dokumentasi, studi pustaka dan wawancara dibandingkan data-nya dengan data dari berbagai sumber perolehan data lainnya sehingga dapat teruji kebenarannya, apakah data tersebut valid atau tidak.

Irawanto mengatakan, kekuatan yang dimiliki oleh media komunikasi massa berbentuk 
film memiliki kemungkinan besar untuk mempersuasi dan mempengaruhi khalayak dalam segmen sosial yang luas. Banyak penelitian yang menunjukkan bahwa hubungan khalayak (penonton) dengan film yang ditonton nya dimengerti secara efektif. Dari data tersebut maka kita dapat mengetahui bahwa, film dapat mempengaruhi dan mempersuasi masyarakat untuk membentuk pemikiran atau sikap yang sebelumnya dimuat dalam pesan yang disampaikan dalam film dan juga sebaliknya. Film selalu menangkap dan merekam realitas yang terdapat pada masyarakat. Realitas ini lalui diproyeksikan ke dalam layar. (Sobur, 2017 : 127).

Disebutkan juga oleh Goran Hedebro yang dikutip oleh Ibrahim dalam Subandy (2005: 384) bahwa media merupakan pembentuk kesadaran sosial yang mengarahkan penentuan pandangan dari persepsi seseorang terhadap dunia dan masyarakat lingkungan hidup mereka. Ini sesuai juga dengan social learning theory Miller dan Dollard's yang menyebutkan bahwa dari perilaku yang diamati di dalam media, terdapat mekanisme imitasi yang penontonnya akan lakukan dan demonstrasikan. Proses imitasi ini terjadi saat penonton tayangan media tersebut terdorong untuk mempelajari hal tersebut, saat simbol-simbol perilaku yang dipelajari muncul, dan saat penonton berniat secara positif untuk menetapkan sikapnya mengimitasi perilaku itu. (Subandy, 2005: 385)

Dalam film sendiri, pesan yang ditampilkan merupakan realitas imajiner yang menyajikan berbagai rasa keindahan, pengetahuan maupun sekedar hiburan. Dengan aspek audio visual yang ditawarkan dari suatu film, ini menjadikan film sangat efektif untuk dijadikan sebuah media dalam menyampaikan pesan karena adanya lambang-lambang dan tanda yang dapat dipahami pada bahasa gambar dan antara dialog dengan gambar.

Menyampaikan pesan di dalam sebuah film mewajibkan kita untuk melakukan suatu kegiatan komunikasi. Dalam menyampaikan pesan-pesan lingkungan melalui komunikasi, ada yang disebut dengan komunikasi lingkungan. komunikasi lingkungan merupakan pertukaran informasi, pengetahuan dan bahkan kebijaksanaan yang ditunjukkan oleh masyarakat mengenai lingkungan itu sendiri.

Aspek kesadaran lingkungan termasuk ke dalam sebuah komunikasi lingkungan. Kesadaran lingkungan sendiri tumbuh dari keadaan lingkungan yang semakin hari makin memburuk. Seseorang yang memiliki pengetahuan akan kesadaran lingkungan yang baik dapat terlihat dari cara ia menyikapi lingkungan dan memperlakukannya. Hal yang memicu kesadaran lingkungan seseorang salah satunya merupakan etika yang ia punya pada lingkungan (Neolaka, 2008). Dalam rancangan pendidikan lingkungan yang disampaikan, diajarkan bahwa manusia merupakan sebagian kecil dari alam itu sendiri. Konsep ini baik untuk terus masyarakat percayai dan sadari bahwa memang manusia bukanlah "penakluk alam" tetapi manusia memang dilahirkan setara dengan alam itu sendiri.

Seperti Teori Biosentrisme yang mendasarkan moralitas dari keseluruhan kehidupan. Dengan begitu kita dapat mengetahui bahwa setiap makhluk hidup yang diciptakan di dalam muka bumi ini bernilai moral yang sama dan seimbang sehingga kita tidak bisa menganggap manusia sebagai makhluk yang lebih berkuasa. Di dalam Teori Biosentrisme, manusia sama sekali tidak dipandang dominan sehingga tidak mempunyai hak untuk mengatur dan menguasai alam untuk kepentingannya. Dalam teori ini, manusia hanyalah bagian lain dari alam semesta, sehingga teori biosentrisme bertentangan dengan teori antroposentrisme yang menyatakan bahwa manusia lah makhluk yang paling dominan dan berhak melakukan segala hal untuk kepentingannya sendiri tanpa mempedulikan lingkungan dan makhluk hidup lainnya.

Dalam penyampaian komunikasi di dalam film, pesan yang ingin disampaikan diolah menjadi sebuah tanda. Tanda merupakan hal fisik yang dapat diterima dan ditangkap oleh indra yang kita miliki; berdasar pada hal yang bukan dirinya sendiri; juga bergantung kepada penggunanya yang mengetahui bahwa itu adalah tanda. (Fiske, 2014:68)

Charles Peirce dalam buku Pesan, Tanda, dan Makna (Danesi, 2010:39) mengidentifikasi 66 jenis tanda yang berbeda, dan tiga di antaranya lazim digunakan dalam berbagai karya semiotika kini, ketiganya adalah ikon, indeks dan simbol. 
Tabel 1. Tiga Jenis Tanda Charles Pierce

\begin{tabular}{|c|l|l|}
\hline $\begin{array}{c}\text { Jenis } \\
\text { Tanda }\end{array}$ & \multicolumn{1}{|c|}{$\begin{array}{c}\text { Hubungan antara tanda dari } \\
\text { sumber Acuannya }\end{array}$} & \multicolumn{1}{c|}{ Contoh } \\
\hline Ikon & $\begin{array}{l}\text { Tanda dirancang untuk } \\
\text { merepresentasikan sumber acuan } \\
\text { melalui simulasi atau persamann } \\
\text { (artinya, sumber acuan dapat dilihat, } \\
\text { didengar, dan seterusnya, dalam ikon }\end{array}$ & $\begin{array}{l}\text { Segala macam gambar } \\
\text { (bagan, diagram, dan } \\
\text { lain-lain). Photo, kata } \\
\text { kata onomatopoeia dan } \\
\text { seterusnya }\end{array}$ \\
\hline Indeks & $\begin{array}{l}\text { Tanda dirancang untuk } \\
\text { mengindikasikan sumber acuan atau }\end{array}$ & $\begin{array}{l}\text { Jari yang menunjuk kaa } \\
\text { keterangan seperti disini, } \\
\text { di sana, kata ganti seperti } \\
\text { aku, kau, ia dan } \\
\text { saling mneghubungkan sumber acuan, } \\
\text { seterusnya }\end{array}$ \\
\hline Simbol & $\begin{array}{l}\text { Tanda yang dirancang untuk } \\
\text { menyandikan sumber acuan melalui } \\
\text { kesepakatan atau persetujuan }\end{array}$ & $\begin{array}{l}\text { Simbol sosial seperti } \\
\text { mawar, simbol } \\
\text { matematika, } \\
\text { seterusnya dan }\end{array}$ \\
\hline
\end{tabular}

Sumber: Buku Pesan, Tanda, Makna (Danesi, 2010:39)

Pendekatan yang digunakan dalam penelitian ini adalah pendekatan semiotika oleh John Fiske. John Fiske berpendapat bahwa komunikasi selalu melibatkan tanda (sign) dan kode (code). Tanda menandakan construct, dan kode adalah sistem dimana tanda-tanda diorganisasikan dan yang menentukan bagaimana tanda-tanda itu mungkin berhubungan satu sama lain dan membentuk sebuah makna. Melalui teori ini, Fiske juga menjelaskan bahwa realitas tidak semata-mata terbentuk melalui kode yang ada, tetapi juga disaring dan diolah melalui pandangan sesuai pengetahuan yang dimiliki oleh penonton televisi, yang menjadikan sebuah kode akan diolah dan simengerti secara berbeda oleh setiap individunya.

Menurut Fiske, dalam Pah, dalam kumpulan jurnal Communicare LSPR (Wijayanto dan Xenia Angelica (ed.) 2019:8), peristiwa dalam suatu tayangan (televisi) akan menjadi peristiwa televisi jika telah di-encode oleh kode sosial yang dikonstuksi dalam beberapa level yang bertahap yaitu level realitas (reality), level representasi (representation) dan level ideologi (ideology).

Gambar 2. SEQ Gambar \* ARABIC \s 11 Tahapan Analisis Tiga Tahap John Fiske

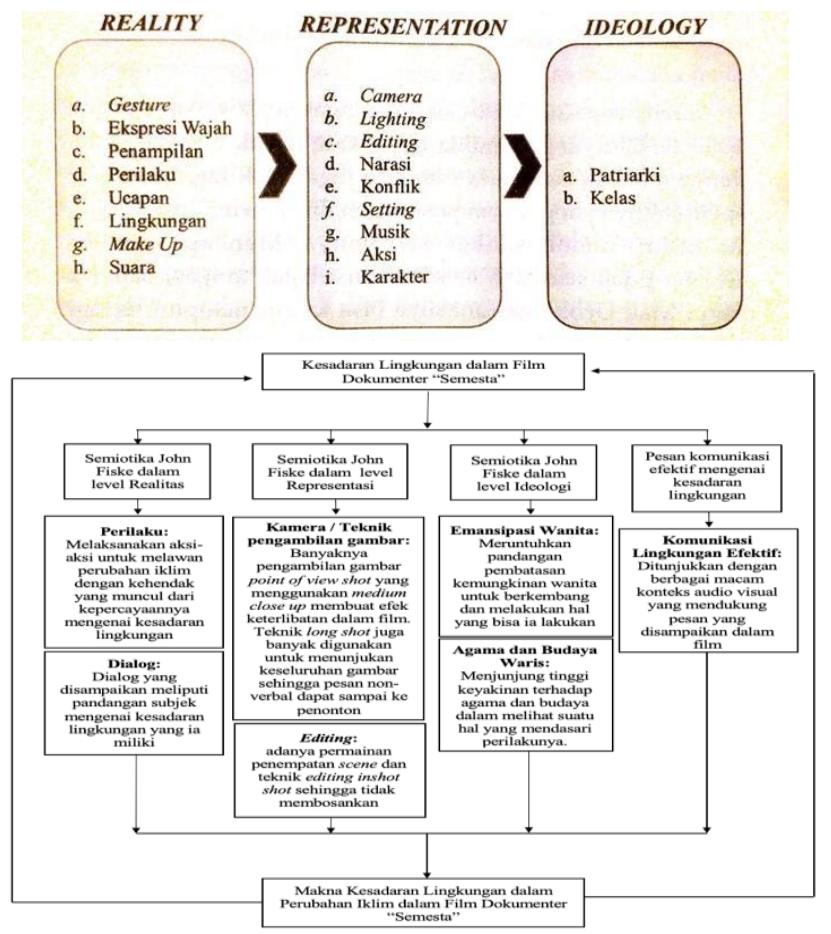

Pengumpulan data pada penelitian ini, berdasarkan kebutuhan analisa dan pengkajian, peneliti menggunakan teknik pengumpulan data studi teks visual, dokumentasi, studi pustaka, 
dan wawancara yang terbagi menjadi data primer dan sekunder.

Analisis data dilakukan dengan menggunakan teknik analisis semiotika oleh John Fiske, di mana terdapat 3 level yang dikemukakan untuk menganalisa elemen dari film tersebut, yaitu level of reality, level of representation, dan level of ideology.

Tabel 2. Tiga Level Semiotika John Fiske

\begin{tabular}{|l|l|}
\hline Level Pertama: & $\begin{array}{l}\text { Dalam televisi ditampilkan sebagai pakaian, riasan, penampilan, } \\
\text { lingkungan, perilaku, gestur, ekspresi, dan ucapan. Peneliti } \\
\text { mengumpulkan dan menjelaskan hal tersebut secara rinci. }\end{array}$ \\
\hline $\begin{array}{l}\text { Level Kedua: } \\
\text { (Representation) }\end{array}$ & $\begin{array}{l}\text { Level ini ditandakan dengan kode teknikal yang mampu menjelaskan } \\
\text { bagaimana objek digambarkan dengan segala bentuk teknis. Dalam } \\
\text { televisi hal ini merupakan kamera, tata cahaya, suara dan musik, } \\
\text { pengeditan dan lainnya. }\end{array}$ \\
\hline $\begin{array}{l}\text { Level Ketiga: } \\
\text { Ideologi (Ideology) }\end{array}$ & $\begin{array}{l}\text { Elemen-elemen dikategorikan dalam kode yang ideologis. Kode-kode } \\
\text { tersebut seperti patriarki, individualisme, kapitalisme, ras, kelas, dan } \\
\text { lainnya. }\end{array}$ \\
\hline
\end{tabular}

Sumber: Diolah oleh penelitii (2021)

Data yang sudah diperoleh diuji menggunakan teknik triangulasi, sehingga data tersebut dapat dipahami sesuai dengan maksud dan tujuan penelitian sebagaimana mestinya. Triangulasi yang digunakan dalam penelitian ini adalah triangulasi sumber, di mana hasil data pengamatan yang sudah terkumpul seperti data studi teks visual, dokumentasi, studi pustaka dan wawancara dibandingkan data-nya dengan data dari berbagai sumber perolehan data lainnya sehingga dapat teruji kebenarannya, apakah data tersebut valid atau tidak. Setelah itu data di rincikan dan di klasifikan perbedaan data, kesamaan data dan juga data mana yang berasal dari data sumber. Lalu data di analisis dan dibahas sampai pada kesimpulan yang akhirnya mencapai titik temu yang sama dari sumber-seumber data lainnya.

\section{Hasil Penelitian dan Pembahasan}

Dari berbagai scene yang telah ditentukan dalam penelitian ini, film "semesta" menggambarkan kode-kode yang ditampilkan dalam tiga level semiotika John Fiske yaitu: realitas, representasi dan ideologi. Dalam level realitas, film ini menampilkan kode perilaku dan dialog yang mencakup nilai-nilai kesadaran lingkungan. Dalam level representasi, film ini menampilkan kode-kode kamera / teknik pengambilan gambar dan editing yang mendukung pembuatan suasana dalam penyampaian pesan terkait. Sedangkan dalam level realitas, kode yang ditampilkan merupakan kode mengenai emansipasi wanita dan agama juga budaya waris. Dengan ditampilkan-nya kode-kode tersebut dalam film ini, tergambar juga suatu pesan efektif mengenai kesadaran lingkungan.

Dalam level realitas, analisis-nya difokuskan terhadap gambaran dari tayangan perilaku dan ucapan yang dilakukan oleh tokoh-tokoh utama dari setiap scene nya. Film ini merupakan film dokumenter yang menceritakan tentang tujuh tokoh di tujuh daerah di Indonesia yang melakukan hal-hal inspiratif, yang berdampak positif bagi lingkungan di sekitarnya. Dari analisis yang telah dilakukan mengenai ketujuh scene film yang sebelumnya telah dipilih, film "Semesta" memperlihatkan banyak bentuk kesadaran lingkungan yang dimilki oleh setiap tokoh utama dan tokoh lainnya di setiap scene diteliti. Seperti yang dikatakan oleh Neolaka (2008) bahwa kesadaran lingkungan salah satunya adalah adanya perubahan konsep mengenai etika lingkungan mengenai konsep nilai manusia adalah bagian dari alam dan bukanlah sebagai penakluk alam (lebih superior).

Kesadaran lingkungan yang tergambar dari perilaku tokoh-tokoh dan masyarakat di dalam film semesta ini juga pada akhirnya menggambarkan suatu komunikasi lingkungan. Dimana komunikasi lingkungan seperti yang kita tahu, bahwa intinya merupakan suatu 
pertukaran informasi, penerapan strategi maupun prinsip dan teknik komunikasi dalam melakukan pengelolaan atau perlindungan terhadap lingkungan.

Dari setiap aksi dan perkataan dialog yang ditampilkan oleh orang-orang di dalam film "semesta", peneliti mendapatkan bahwa pembuat film "semesta" ingin menunjukkan sebuah cerminan kesadaran lingkungan yang orang-orang di dalam film ini miliki kepada orang banyak. Karena seperti apa yang dijelaskan oleh teori agenda setting dalam Ritonga (2018:34), bahwa media mempunyai kemampuan untuk dapat memberitahu khalayak apa yang penting untuk mereka dan bukan memberitahu apa yang khalayak anggap penting. Pembuat film "semesta" ingin memperlihatkan bahwa aksi-aksi peduli lingkungan yang dilakukan oleh tokoh di dalam film tersebut merupakan hal yang perlu untuk orang banyak juga lakukan untuk sama-sama berjuang melawan perubahan iklim lingkungan bumi.

Dalam level representasi, analisis difokuskan pada teknik pengambilan gambar dan editing yang ada di setiap scene terpilih. Teknik-teknik kamera yang digunakan dalam setiap pengambilan gambar film ini, sangat mendukung pesan-pesan yang ingin disampaikan pembuat film kepada penontonnya. Melihat dari berbagai ragam teknik pengambilan gambar yang digunakan dalam film ini, teknik yang banyak digunakan dalam mengambil gambar di film ini yaitu teknik gambar point of view shot dan inshot shot.

Teknik-teknik pengambilan gambar yang dipilih oleh pembuat film mempunyai artinya tersendiri. Seperti dalam film ini, dengan menggunakan banyak teknik pengambilan gambar point of view shot, di mana teknik ini menempatkan kamera disamping atau didepan objek orang yang sedang di wawancara, tanpa adanya tata[ mata dengan kamera. Kamera dihadirkan dengan sudut pandang orang ketiga yang membuat efek seolah-olah orang yang menonton ikut masuk ke dalam momen percakapan tersebut.

Sedangkan dalam teknik editing inshot shot, teknik ini merupakan teknik pemasukan sisipan gambar yang diambil oleh cameraman saat proses shooting Tujuan inshot shot ini di masukan dan di sisipkan di dalam film adalah agar penonton tidak bosan saat melihat satu scene yang pengambilan gambarnya tidak beragam. Seperti dalam pengambilan gambar point of view shot, yang diperlihatkan hanyalah teknik pengambilan gambar medium close up pada seseorang yang sedang berbicara mengenai penjelasan tentang suatu hal. Jika pengambilan gambar tersebut tidak di sisipkan gambar lainnya dengan inshot shot, film tersebut akan menjadi monoton dan tidak menarik bagi penontonnya.

Teknik pengambilan gambar lainnya juga tak kalah penting dalam pengemasan suatu film. Selain kedua teknik pengambilan gambar yang sering dijumpai di dalam film "semesta" yang sebelumnya dijelaskan, ada beberapa teknik gambar lainnya berperan penting dalam pembuatan suasana yang mendukung penyampaian pesan. Seperti teknik pengambilan dari jarak jauh atau long shot, teknik ini berguna untuk menunjukkan keseluruhan objek maupun keadaan disekitar sehingga penonton dapat melihat jelas apa yang terjadi dengan jelas dan akhirnya dapat mengolah gambar yang mereka tangkap secara menyeluruh ke dalam persepsi mereka sendiri tentang apa makna dan maksud yang ada di dalamnya.

Teknik artificial framing shot juga kerap dijumpai di dalam pengambilan gambar dalam film ini. Begitu pula permainan camera angle yang tak kalah penting untuk diperhatikan. Di film "semesta" camera angle yang sering digunakan adalah high angle dan eye level, walaupun ada juga angle lain yang digunakan seperti bird eye view dan frog eye view

Dalam level ideologi, digambarkan gambaran besar mengenai ideologi yang tergambar dalam film "Semesta" merupakan agama dan budaya atau adat istiadat. Seperti keterangan Malik dari Bandung Film Commission, bahwa film ini mengangkat berbagai perspektif agama seperti Hindu, Islam, Kristen, yang menunjukkan bahwa ternyata manusia mempunyai hubungan dengan alam, bahwa ideologi yang kita percayai bisa membuat kita bersikap berbeda kepada alam. Dan hal ini bersangkutan dengan tema besar yang diangkat oleh film maker dari film "Semesta" ini, bahkan judulnya saja sudah "Semesta", semesta itu kan alam, universe, itu adalah gagasan cosmic. Dan gagasan-gagasan tersebut ada didalam agama juga kepercayaankepercayaan. Dari gagasan yang disampaikan melalui agama dan kepercayaan itulah yang akhirnya membuat orang-orang di dalam film "Semesta" akhirnya mempunyai pemikiran bahwa alam merupakan sebuah bagian dari hidup mereka. Agama sendiri memberikan arahan-arahan 
dan tutunan bagi umatnya untuk berperilaku, bagaimana kita harus bersikap kepada sesama manusia, kepada alam dan juga kepada penciptanya.

Selain agama, ada juga ideologi lainnya yang tersirat dalam film ini, yaitu emansipasi wanita. Ideologi mengenai emansipasi wanita terkandung di dalam scene ke-empat dan ke-tujuh, di mana digambarkan bahwa kegiatan Sasi yang dilaksanakan di Kapatcol dilaksanakan seluruhnya oleh wanita dengan dukungan dari pihak gereja. Dikatakan oleh salah satu narasumber, Bapak Askurifa'i, bahwa tokoh ini sepertinya dipilih untuk memberikan pesan juga bahwa di Papua pun ada gerakan emansipasi bahwa wanita juga bisa melakukan hal-hal atas kehendaknya sendiri karena wanita pun memiliki hak untuk itu. Disebutkan juga di dalam scene tersebut bahwa sebelum adanya gerakan Sasi di Desa ini yang dilakukan oleh perempuan sebagai seluruh anggotanya tahun 2010, gerakan Sasi ini selalu dilaksanakan dengan adanya peran pria di dalamnya. Hal ini menunjukkan kesetaraan kedudukan sosial antara wanita dan pria, bahwa wanita bisa melakukan sesuatu dengan hak untuk dirinya dapat berkembang, maju, belajar dan berkarya layaknya juga pria. Begitupun dengan hal yang ditunjukkan di dalam scene ke-tujuh di mana pelopor gerakan bertani urban yang merupakan seorang perempuan.

Pesan komunikasi yang disampaikan film "semesta" mengenai kesadaran lingkungan dinilai efektif. Film ini mampu menyampaikan bahwa kesadaran lingkungan dapat membuat orang sadar akan pentingnya merawat lingkungan. Karena dengan merawat lingkungan, kita akan mendapatkan manfaat yang baik pula dari lingkungan, sebuah timbal balik. Film "semesta" memperlihatkan hal-hal kecil tentang bagaimana kita bisa menanamkan kesadaran lingkungan melalui tokoh-tokoh yang melakukan berbagai macam cara dan aktivitasnya dalam merawat alam, atau paling tidak dalam garis kecil lingkungan sekitarnya. Dalam Sobur (2017:127), Irawanto mengatakan bahwa media komunikasi film mempunyai kekuatan untuk mempersuasi dan mempengaruhi khalayak karena film menangkap dan merekam realitas yang terdapat dalam masyarakat lalu diproyeksikan ke dalam layar. Sehingga, orang-orang yang seudah menonton film tersebut akan memiliki interaksi yang dikenal dengan sebutan mediated relationship, kemudian proses mediated relationship dapat dilihat dari bentuk identifikasi dan interaksi parasosial. Identifikasi dan interaksi parasosial merupakan konsep yang berbicara tentang bagaimana cara penonton terlibat dalam film dan mengolah pesan di dalamnya. Pada bentuk identifikasi, penonton mengalami keterlibatan dengan "karakter" yang menjadi fokus perhatiannya, lalu penonton mengadopsi perspektif karakter (as character). Dan akhirnya penonton pun akan terpersuasi dan terpengaruhi untuk melakukan hal yang sama seperti apa yang kaakter dalam film itu lakukan, dalam hal ini merawat lingkungan berdasarkan kesadaran lingkungan yang seseorang miliki.

Menurut sosial learning theory juga yang disebutkan dalam Subandy (2005: 385) bahwa terdapat proses mekanisme imitasi yang dilakukan penonton akan hal yang mereka dapatkan dalam suatu tayangan. Perilaku mengenai pesan yang ditayangkan dan disampaikan merupakan pesan mengenai bagaimana kita bisa menimbulkan kesadaran lingkungan kita dan akhirnya berbuat sesuatu yang baik untuk lingkungan. Pesan tersebut dikemas dengan memperlihatkan kegiatan-kegiatan positif di dalam film seperti kegiatan bertani, gotong royong warga, diskusi dan hal positif lainnya yang dilakukan atas kehendak dan kemauan orang-orang tersebut tanpa adanya paksaan untuk melakukan hal tersebut.

Selain itu, penyajian pesan melalui media audio visual film menjadikan film sebagai sebuah media yang efektif untuk dijadikan sebuah media penyampaian pesan, salah satunya pesan mengenai kesadaran lingkugan. Seperti yang disebutkan Effendy dalam Tohdjoyo (2018:38-39) bahwa penyampaian pesan melalui aspek audio visual berarti film berkomunikasi dengan menggunakan bahasa verbal dan non-verbal. Ini artinya selain dari dialog yang disampaikan, pesan juga bisa terkandung dalam gaya dan gerak gerik tubuh, ekspresi muka, sikap, teknik pengambilan gambar, properti, OST, dan unsur non-verbal lainnya yang tercakup dalam sebuah film sehingga akhirnya pesan yang disampaikan dapat tergambar dengan jelas dari berbagai macam aspek komunikasi yang ditampilkan.

\section{Kesimpulan}

Berdasarkan Berdasarkan hasil dari keseluruhan penelitian dari "Kesadaran Lingkungan dalam 
Perubahan Iklim dalam Film Dokumenter 'Semesta" sesuai dengan pembahasan yang sebelumnya sudah dijelaskan dan batasan-batasan identifikasi masalah juga tujuan yang ingin dicapai, peneliti dapat menyimpulkan bahwa adanya nilai kesadatan lingkungan dalam film semesta yang digambarkan pada:

1. Kesadaran Lingkungan pada Level Realitas Semiotika John Fiske

Aspek kesadaran lingkungan dalam level realitas dapat dilihat dari kode televisi aspek perilaku dan dialog dalam film "semesta", di mana pada kode perilaku, diperlihatkan orang-orang yang ada di dalam film tersebut melakukan berbagai kegiatan untuk melawan perubahan iklim berdasar dari kesadaran lingkungan mereka. Sedangkan dari kode dialog digambarkan bahwa orang-orang di dalam film tersebut menyampaikan pandangan-nya mengenai kesadaran lingkungan yang dimilkinya.

2. Kesadaran Lingkungan pada Level Representasi Semiotika John Fiske

Aspek kesadaran lingkugan dalam level representasi yang ditampilkan di dalam film "Semesta" ini ditunjukkan oleh kode kamera dan kode editing. Di mana pada aspek pengambilan gambar ditunjukkan banyaknya point of view shot, medium close up dan teknik long shot yang menciptakan efek keterlibatan penonton di dalam film tersebut dan agar penonton bisa melihat objek gambaran secara luas. Sedangkan pada aspek editing adanya pengemasan film dengan memasukan teknik edit inshot shot dan dengan mengatur penempatan gambar yang tepat menghasilkan suatu cerita yang baik dalam penyampaian pesannya sehingga dapat dipamahi oleh penontonnya.

3. Kesadaran Lingkungan pada Level Ideologi Semiotika John Fiske

Film "Semesta" secara umum menggambarkan nilai kesadaran lingkungan yang didasari oleh kepercayaan agama dan budaya yang dimiliki oleh masyarakat dan tokoh-tokoh yang ada di dalam film tersebut. Ini menunjukkan bahwa nilai-nilai agama dan budaya berpengaruh ke dapam suatu konstruksi pikiran bagaimana seseorang dapat memandang suatu hal. Dalam film ini juga tersirat ideologi dari emansipasi wanita, di mana wanita bisa memilih dan melakukan hal dan kemungkinan apapun untuk berkembang dan memajukan hidupnya.

4. Pesan Komunikasi yang Efektif Mengenai Kesadaran Lingkungan

Pesan komunikasi yang disampaikan melalui film ini efektif disampaikan kepada penontonnya. Dengan menggunakan banyak unsur komunikasi audio-visual, verbal dan non-verbal, film ini dapat membuat sebuah cerita secara keseluruhan dengan padu sehingga menghasilkan pesan-pesan efektif yang dapat diterima oleh penontonnya.

\section{Acknowledge}

Peneliti mengucapkan terimakasih kepada seluruh pihak yang telah membantu peneliti dalam menyelesaikan penelitian ini. Terimakasih kepada seluruh informan dan juga pihak lainnya yang tak pernah luput dalam membimbing peneliti menyelesaikan penelitian ini.

\section{Daftar Pustaka}

[1] Danesi, Marcel. 2010. Pesan, Tanda, dan Makna. Yogyakarta : Jalasutra

[2] Fiske, John. 2014. Pengantar Ilmu Komunikasi: Edisi Ketiga. Jakarta:Rajawali Press

[3] Greenpeace Indonesia. 2020. Tantangan Kita Bersama di Tahun 2020. https://www.greenpeace.org/indonesia/cerita/4544/tantangan-kita-bersama-di-tahun-2020/ Tanggal akses 31 Agustus 2020, pukul 03.57 WIB

[4] McQuail, Denis. 2011. Teori Komunikasi Massa McQuail, Edisi 6 Buku 1. Jakarta: Salemba Humanika

[5] MD Pictures. 2019. Jumlah Penonton Film di Indonesia Tahun 2015-2019. https://www.idx.co.id/StaticData/NewsAndAnnouncement/ANNOUNCEMENTSTOCK/Fr om_EREP/201912/3cf32371dc_85b5efd556.pdf. Tanggal akses 9 September, pukul 15.44 WIB

[6] Neolaka, Amos. 2008. Kesadaran Lingkungan, Jakarta: Rineka Cipta

[7] National Geographic. 2019. "'Skenario 2050', Prediksi Penelitian Tentang Kepunahan 
Manusia dalam $30 \quad$ Tahun Mendatang”. https://nationalgeographic.grid.id/read/131766300/skenario-2050-prediksi-peneliti-tentangkepunahan-manusia-dalam-30-tahun-mendatang?page=all. Tanggal akses 1 Oktober, pukul 19.00

[8] National Geographic. 2020. "Film Semesta, Kisah 7 Sosok yang Berusaha Memperlambat Dampak Perubahan Iklim”. https://nationalgeographic.grid.id/read/131997205/filmsemesta-kisah-7-sosok-yang-berusaha-memperlambat-dampak-perubahan-iklim. Tanggal akses 1 Oktober, pukul 18.28 WIB

[9] Ritonga, Elfi Yanti. 2018. Teori Agenda Setting dalam Ilmu Komunikasi. Sumatera Utara: Universitas Islam Negeri Sumatera Utara.

[10] Sobur, Alex. 2017. Semiotika Komunikasi. Bandung: PT. Remaja Rosdakarya

[11] Subandy, Dede Lilis Ch., 2005. Represetasi Simbolik Film Kartun "Dora the Explorer": Ethnographic Content Analysis dalam Jurnal Mediator Vol.8, No.2, Tahun 2007, halaman 384-385.

[12] Tohdjoyo, Fahmi Muhammed. 2018. Representasi Nilai-Nilai Islam dalam Tayangan Film (Analisis Deskriptif terhadap Film Bulan Terbelah di Langit Amerika). Malang: Universitas Muhammadiyah Malang

[13] Wijayanto dan Xenia Angelica (ed.). 2019 . Communicare Journal of Communication Studies. Jakarta: Research Centre and Publication Department LSPR Jakarta 